\title{
Pengaruh Pelatihan dan Pendidikan terhadap Pengembangan Karir Karyawan pada Satuan Kerja Non Vertikal Tertentu (SNVT) Pembangunan Jalan dan Jembatan Provinsi NTB
}

\author{
Irwan Cahyadi \\ irwancahyadi@universitasbumigora.ac.id \\ Universitas Bumigora \\ Isra Dewi Kuntary Ibrahim \\ israibrahim@universitasbumigora.ac.id \\ Universitas Bumigora \\ Rini Anggriani \\ rinianggriani@universitasbumigora.ac.id \\ Universitas Bumigora \\ Raden Bagus Faizal Irany Sidharta \\ raden.sidharta@universitasbumigora.ac.id \\ Universitas Bumigora
}

\begin{abstract}
The purpose of this study was to determine the significance of the effect of components of education and training programs such as materials, teaching staff, methods, time, location and facilities on the career development of employees in Certain Non-Vertical Work Units (SNVT) for Road and Bridge Construction of NTB Province, both partially and simultaneously. The type of research used is descriptive research and uses a sample survey method in collecting data. The data collection tool used is a questionnaire, in which each variable being studied is made up of measurement indicators arranged in the relevant questionnaire. The analytical tool used in accordance with the objectives of the researcher is multiple linear regression analysis, which is then continued with the F test and $t$ test at 5\% alpha. Based on the results of the analysis carried out, it is known that the components of the education and training program such as materials, teaching staff, methods, time, location and facilities have a significant influence on the career development of employees in Certain NonVertical Work Units (SNVT) for Road and Bridge Construction in the Province of NTB. simultaneously or partially. The significance criteria are known based on the $F$ test and test that have been carried out, where $F$ count and t count have a higher value than $F$ table and t table.
\end{abstract}

Keywords : career development, training program

\section{Pendahuluan}

Pelatihan dan pendidikan adalah merupakan upaya untuk mengembangkan sumber daya manusia, terutama untuk mengembangkan kemampuan intelektual dan keperibadian manusia (Eliana, Nurhayati, \& Fathiah, 2020). Pendidikan pada umumnya berkaitan dengan mempersiapkan calon tenaga yang diperlukan oleh suatu instansi atau organisasi, sedangkan pelatihan lebih berkaitan dengan peningkatan kemampuan atatu keterampilan karyawan yang sudah menduduki suatu pekerjaan atatu tugas tertentu. Menurut Wijono (2015), pendidikan dan pelatihan tenaga kerja merupakan salah satu kunci manajemen tenaga kerja, sekaligus merupakan salah satu tugas dan tanggung jawab yang tidak dapat dilaksanakan secara sembarangan. Artinya, agar efektivitas pendidikan dan pelatihan dapat terjamin, perlu penanganan yang serius, baik yang menyangkut sarana maupun prasarananya. 
Salah satu manfaat adanya program pendidikan dan pelatihan adalah pengembangan karir. Dengan adanya pengembangan karir, maka akan mendorong atau memotivasi para pegawainya untuk tetap berproduktivitas. Pengembangan karir juga berguna sebagai salah satu sumber perekrutan tenaga kerja dari dalam perusahaan/instansi (internal). Dengan adanya perekrutan dari dalam perusahaan, perusahaan dapat memberikan kesempatan kepada pegawai yang ada untuk mengembangkan karirnya pada instansi tersebut. Pengembangan karir adalah peningkatan-peningkatan pribadi yang dilakukan seseorang untuk mencapai suatu rencana karir (Wirawan, 2015). Mufidah, Mursito, \& Kustiyah (2020) menyatakan bahwa dalam pengembangan karir terdapat faktor-faktor yang mempengaruhi seperti peningkatan produktivitas, peningkatan jabatan, bekerja lebih efisien dan peningkatan pelayanan yang lebih baik. Pengembangan karir (promosi) merupakan langkah nyata pengembangan karir yang paling diminati karyawan dan sebagai pengembangan yang paling diminati/ditunggu oleh karyawan.

Satuan Kerja Non Vertikal Tertentu (SNVT) Pembangunan Jalan dan Jembatan Provinsi NTB adalah salah satu instansi yang bergerak di bidang non lintas dan lintas negara dengan tugas khusus yaitu mengembangkan jalan dan jembatan. Sebagai salah satu instansi yang melihat manfaat dari pengembangan sumber daya manusia, Satuan Kerja Non Vertikal Tertentu (SNVT) Pembangunan Jalan dan Jembatan Provinsi NTB setiap tahun secara rutin mengadakan program pendidikan dan pelatihan bagi pegawainya. Hal ini diharapkan agar tujuan program pendidikan dan pelatihan yang diberikan oleh Satuan Kerja Non Vertikal Tertentu (SNVT) Pembangunan Jalan dan Jembatan Provinsi NTB dapat tercapai. Sebagaimana tujuan utama dari program pendidikan dan pelatihan yang dikemukakan oleh Swastha \& Handoko (2012) yakni, pertama, pendidikan dan pelatihan dilakukan untuk menutup "gap" (hal yang seharusnya dengan hal sebenarnya terjadi) antara kecakapan atau kemampuan karyawan dengan permintaan jabatan. Kedua, program-program tersebut diharapkan dapat meningkatkan efisiensi dan efektivitas program tersebut sehingga ini dapat membantu menyelesaikan tugastugas dan tanggung jawab para karyawannya dalam mencapai sasaran-sasaran kerja yang telah ditetapkan.

Jenis program pendidikan dan pelatihan yang diadakan oleh Satuan Kerja Non Vertikal Tertentu (SNVT) Pembangunan Jalan dan Jembatan Provinsi NTB diantaranya adalah pelatihan konstruksi bangunan jalan dan jembatan, sistem akuntansi instansi, pengadaan barang dan jasa, serta bimbingan teknik aplikasi daftar isian pelaksanaan anggaran. Program tersebut pada umumnya bertujuan untuk menambah wawasan, pengetahuan, kemampuan dan keterampilan, serta untuk membantu para pegawainya dalam menyelesaikan tugas dan tanggung jawabnya yang berkaitan atau berhubungan dengan hal tersebut. Secara umum, program pendidikan dan pelatihan ini bertujuan untuk meningkatkan kemampuan kerja karyawan. Selanjutnya untuk meningkatkan motivasi kerja karyawan guna meningkatkan kinerjanya, instansi memberikan reward (penghargaan) diantaranya berupa peningkatan gaji dan pengembangan karir.

Pelaksanaan program pendidikan dan pelatihan ternyata berperan penting dalam menentukan pengembangan karir karyawan pada suatu perusahaan/instansi. Sebagaimana yang berlaku pada Satuan Kerja Non Vertikal Tertentu (SNVT) Pembangunan Jalan dan Jembatan Provinsi NTB, di mana program pendidikan dan pelatihan menjadi salah satu syarat bagi karyawan untuk mendapatkan program pengembangan karir. Hal ini sesuai dengan yang dinyatakan oleh Sastrohadiwiryo dalam Nurhasan \& Saoqi (2016) bahwa kriteria untuk melakukan promosi diantaranya adalah adanya kualifikasi pendidikan dan prestasi kerja. Selain dapat mempengaruhi pengembangan karir karyawan, program pendidikan dan pelatihan juga mempengaruhi penilaian prestasi kerja karyawan. Ini menunjukkan bahwa program pendidikan dan pelatihan dapat berpengaruh langsung maupun tidak langsung terhadap pengembangan karir karyawan. 


\section{Kajian Teori}

\subsection{Pendidikan dan Pelatihan}

Menurut Dessler (2015), pendidikan (formal) di dalam suatu organisasi merupakan suatu proses pengembangan kemampuan ke arah yang diinginkan oleh organisasi yang bersangkutan. Sedangkan pelatihan (training) ialah merupakan suatu proses pendidikan, yang tujuannya untuk meningkatkan kemampuan atau keterampilan khusus seseorang atau sekelompok orang. Oleh karena itu, untuk dapat meningkatkan kinerja seorang karyawan, maka karyawan yang bersangkutan harus diberikan pendidikan dan pelatihan sehingga kemampuan mereka dapat ditingkatkan dalam rangka meningkatkan kinerja.

Menurut Mathis \& Jackson (2012) dalam teori pendidikan dan pelatihan, faktor yang mempengaruhi keberhasilan program pendidikan dan pelatihan dibedakan menjadi dua, yakni apa yang disebut perangkat lunak (software) dan perangkat keras (hardware). Perangkat lunak dalam program pendidikan dan pelatihan mencakup kurikulum, organisasi pendidikan dan pelatihan, peraturan-peraturan, metode belajar mengajar, dan tenaga pengajar atau pelatih itu sendiri. Sedangkan perangkat keras (hardware) yang juga besar pengaruhnya terhadap proses diklat ialah fasilitas-fasilitas yang mencakup gedung, perpustakaan (buku-buku referensi), alat bantu pendidikan, dan sebagainya. Berikut ini dijelaskan mengenai faktor-faktor yang mempengaruhi program pendidikan dan pelatihan :

1) Materi pendidikan dan pelatihan

Apa yang harus dibahas dalam latihan haruslah dihubungkan dengan kebutuhan organisasi yang mengirimkan peserta latihan yang bersangkutan. Dengan kata lain subyek, atau materi yang dibahas dalam sesuatu latihan haruslah ada hubungannya dengan usaha untuk merealisir apa yang menjadi tujuan training yang bersangkutan (Prasetyo \& Relawan, 2017)

2) Waktu atau jadwal pendidikan dan pelatihan Jadwal latihan yang tepat, sangat berpengaruh untuk efektivitas suatu program latihan. Ia harus bersesuaian atau disesuaikan dengan keinginan para peserta, terlebih pula harus dipilih waktu dengan melihatnya dari sudut produktivitasnya (Umiyati, Anwar, \& Ustadztama, 2020)

3) Tenaga pengajar atau instruktur pendidikan dan pelatihan

Ada tiga kualifikasi penting, yang harus dipenuhi oleh setiap instruktur yaitu pengetahuan yang mendalam mengenai topiknya, faham akan berbagai metode training, dan adanya keinginan untuk mengajar (Hadjri \& Perizade, 2019)

4) Metode pendidikan dan pelatihan

Dalam suatu program diklat, harus jelas metode yang bagaimana yang cocok dengan jenis pendidikan dan pelatihan serta tujuan yang diharapkan dari penyelenggaraannya (Handayani, 2019)

5) Lokasi atau tempat pendidikan dan pelatihan

Dalam menetapkan lokasi sesuatu latihan perhatian harus diarahkan kepada kemungkinan selain pemberian fasilitas bagi pelaksanaan latihan, tetapi pula suasana yang sebaik mungkin, sehingga peserta latihan merasakan suasana yang kondusif untuk belajar. Sebaiknya harus jauh dari tempat pekerjaan sehari-hari, maksudnya untuk mengurangi interupsi dan pula agar dapat menaikkan tingkat konsentrasi dari peserta latihan terhadap pelajarannya (Sartika, 2018)

6) Fasilitas pendidikan dan pelatihan

Penyediaan tempat dan alat-alat harus didasarkan pada prinsip ekonomi serta berpedoman pada sasaran pengembangan yang ingin dicapai. Misalnya: tempat pengembangan hendaknya strategis, tenang, nyaman, dan tidak mengganggu lingkungan. Mesin-mesin yang digunakan dalam pengembangan sama jenisnya dengan mesin yang akan digunakan dalam bekerja pada perusahaan (Azizah, 2019)

Untuk menilai keberhasilan program pendidikan dan pelatihan, manajemen harus mengevaluasi kegiatan pendidikan dan pelatihan secara sistematis. Secara ringkas, evaluasi program pendidikan dan pelatihan dapat digambarkan seperti gambar berikut : 


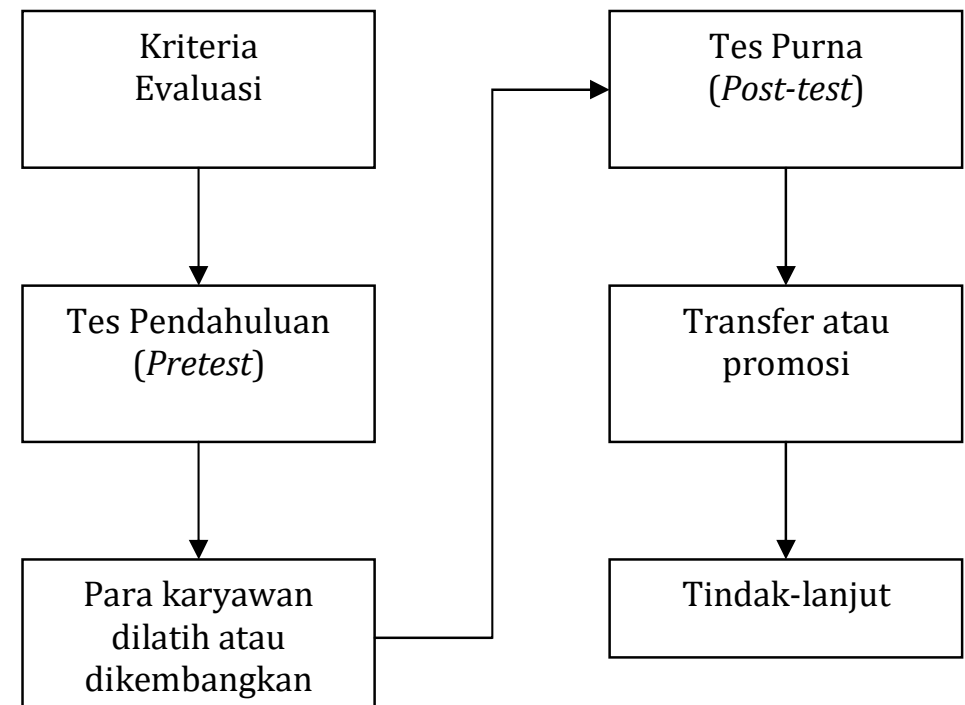

Gambar 1. Evaluasi Program Pendidikan dan Pelatihan (Handoko, 2011a)

Berdasarkan gambar di atas dapat dijelaskan bahwa tahap pertama dalam mengevaluasi program pendidikan dan pelatihan adalah kriteria evaluasi, dalam hal ini perusahaan/intansi melakukan indentifikasi kebutuhan program pendidikan dan pelatihan. Tahap kedua yaitu tes pendahuluan (pretest), pada tahap ini tujuan perusahaan diantaranya adalah untuk mengetahui kemampuan peserta pada saat sebelum mendapatkan program pendidikan dan pelatihan. Tahap ketiga adalah para karyawan dilatih atau dikembangkan, pada tahap ini para peserta pendidikan dan pelatihan akan diberikan ilmu pengetahuan dan keterampilan yang berhubungan dengan pekerjaannya di perusahaan. Tahap keempat adalah tes purna (post-test), pada tahap ini peserta akan dites kemampuannya setelah mendapatkan program pendidikan dan pelatihan. Tahap kelima adalah transfer atau promosi, pada tahap ini setelah peserta mengikuti program pendidikan dan pelatihan, maka karyawan tersebut akan mendapatkan transfer atau promosi jabatan oleh perusahaan dari posisi sebelumnya. Tahap terakhir adalah tindak lanjut, pada tahap setelah karyawan mendapatkan transfer atau promosi jabatan maka perusahaan akan menindak lanjuti karyawan tersebut.

\subsection{Pengembangan Karir}

Menurut Handoko (2011), karir (career) adalah seluruh pekerjaan (jabatan) yang ditangani atau dipegang selama kehidupan kerja seseorang. Dalam karir terdapat sasaransasaran karir yaitu posisi di waktu yang akan datang di mana seseorang "berjuang" untuk mencapainya sebagai bagian dari karirnya. Perencanaan karir (career planning) adalah proses melalui mana seseorang memilih sasaran karir, dan jalur ke sasaran tersebut. Pengembangan karir (career development) adalah peningkatan-peningkatan pribadi yang dilakukan seseorang untuk mencapai suatu rencana karir atau yang biasa dikenal sebagai promosi. Menurut Sastrohadiwiryo dalam Balbed \& Sintaasih (2019), promosi dapat diartikan sebagai proses perubahan dari satu pekerjaan ke pekerjaan lain dalam hierarki wewenang dan tanggung jawab yang lebih tinggi daripada dengan wewenang dan tanggung jawab yang telah diberikan kepada tenaga kerja pada waktu sebelumnya.

Selanjutnya menurut Sastrohadiwiryo (2003) dalam rangka pelaksanaan program promosi bagi tenaga kerja, perlu ditetapkan kriterianya terlebih dahulu. Kriteria promosi hendaknya dapat dipakai sebagai standar dalam menetapkan siapa yang berhak untuk segera dipromosikan. Oleh karena itu, kriteria yang telah ditetapkan dapat menjamin, bahwa tenaga kerja yang akan dipromosikan memiliki kemampuan untuk memegang jabatan yang lebih tinggi daripada jabatan sebelumnya. Kriteria-kriteria yang dimaksud, antara lain : 
1) Senioritas

Dengan alasan lebih senior, pengalaman yang dimiliki pun dianggap lebih banyak daripada yang junior. Dengan demikian, diharapkan tenaga kerja yang bersangkutan memiliki kemampuan lebih tinggi, gagasan lebih banyak, dan kemampuan manajerial yang lebih baik.

2) Kualifikasi Pendidikan

Alasan yang melatarbelakangi adanya kualifikasi pendidikan adalah dengan pendidikan yang lebih tinggi diharapkan tenaga kerja memiliki daya nalar yang tinggi terhadap prospek perkembangan perusahaan di waktu mendatang.

3) Prestasi kerja

Prestasi kerja yang tinggi memiliki kencenderungan untuk memperlancar kegiatan promosi bagi tenaga kerja yang bersangkutan, dengan demikian pula kecenderungan sebaliknya.

4) Karsa dan Daya Cipta

Untuk kegiatan promosi pada jenis pekerjaan tertentu, barangkali karsa dan daya cipta merupakan salah satu syarat yang tidak perlu ditawar lagi. Hal ini disebabkan untuk jenis pekerjaan tertentu sangat memerlukan karsa dan daya cipta demi kelangsungan perusahaan. Dengan demikian, pelaksanaan promosi bagi tenaga kerja berdampak pada meningkatnya laba yang tinggi daripada waktu sebelumnya.

5) Tingkat Loyalitas

Tingkat loyalitas tenaga kerja terhadap perusahaan seringkali menjadi salah satu kriteria untuk kegiatan promosi. Loyalitas yang tinggi akan berdampak pada tanggung jawab yang lebih besar.

6) Kejujuran

Khusus pada jabatan-jabatan yang berhubungan dengan finansial, produksi, pemasaran, dan sejenisnya, kejujuran dipandang amat penting. Hal ini dimaksudkan untuk menjaga jangan sampai kegiatan promosi malah merugikan perusahaan, karena ketidakjujuran tenaga kerja yang dipromosikan.

7) Supelitas

Pada jenis pekerjaan/jabatan tertentu barangkali diperlukan kepandaian bergaul, sehingga kriteria kemampuan bergaul dengan orang lain perlu dijadikan salah satu standar untuk promosi pada pekerjaan/jabatan tersebut.

\subsection{Kerangka Konseptual}

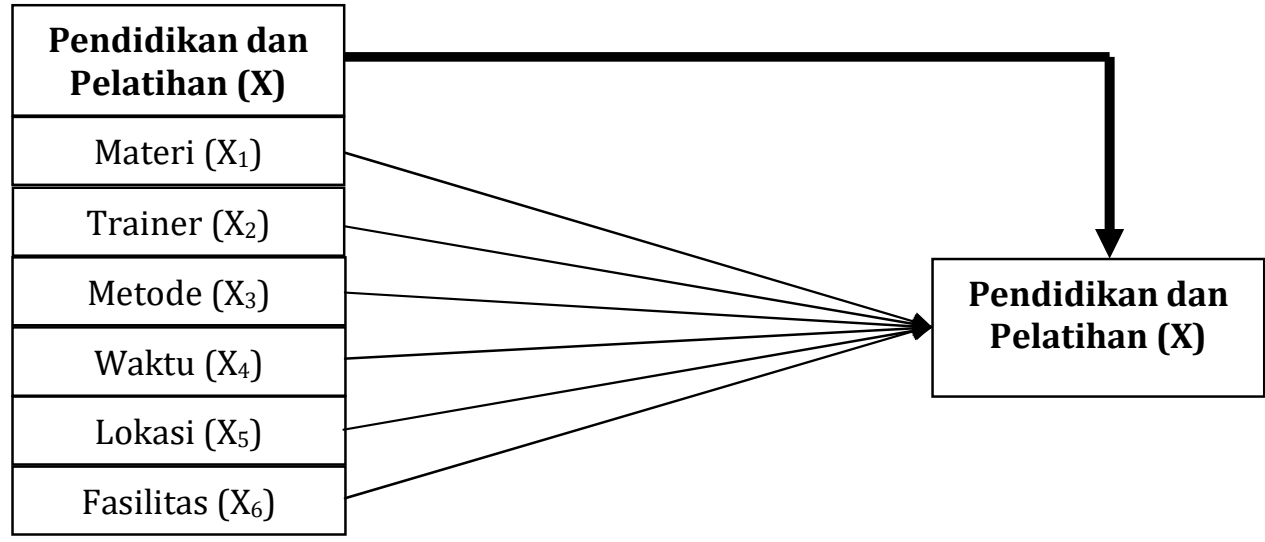

Gambar 2. Kerangka Konseptual Penelitian 


\section{Metode Penelitian}

Jenis penelitian yang digunakan dalam penelitian ini adalah penelitian asosiatif atau sebab akibat (kausal). Menurut Sugiyono (2012), penelitian asosiatif merupakan jenis penelitian yang bertujuan untuk mengetahui hubungan antara dua variabel atau lebih. Dalam penelitian ini, metode asosiatif digunakan untuk mengetahui pengaruh program pendidikan dan pelatihan terhadap pengembangan karir pegawai pada Satuan Kerja Non Vertikal Tertentu (SNVT) Pembangunan Jalan dan Jembatan Provinsi NTB.

Populasi dalam penelitian ini adalah seluruh karyawan Satuan Kerja Non Vertikal Tertentu (SNVT) Pembangunan Jalan dan Jembatan Provinsi NTB yang telah mengikuti program pendidikan dan pelatihan yang sama, yaitu berjumlah 30 orang. Dikarenakan anggota populasi berjumlah sedikit, maka seluruh anggota populasi dijadikan sebagai responden sehingga metode penentuan responden menggunakan sensus. Untuk mengumpulkan data yang berasal dari responden digunakan kuesioner yang selanjutnya diukur dengan menggunakan skala likert. Data yang sudah terkumpul selanjutnya dianalisis dengan alat analisis regresi linier berganda dengan menggunakan uji t dan uji F.

\section{Analisis dan Pembahasan}

\subsection{Hasil Analisis}

\subsubsection{Analisis Regresi Linier Berganda}

Dalam penelitian ini digunakan metode analisis regresi linier berganda, yang digunakan untuk mengetahui besar pengaruh variabel bebas yaitu komponen program pendidikan dan pelatihan yang terdiri dari metode, tenaga pengajar, materi, waktu, lokasi dan fasilitas yang disimbolkan dengan $\mathrm{X}_{1}, \mathrm{X}_{2}, \mathrm{X}_{3}, \mathrm{X}_{4}, \mathrm{X}_{5}$ dan $\mathrm{X}_{6}$ terhadap variabel terikat yaitu pengembangan karir yang disimbolkan dengan $\mathrm{Y}$. Berdasarkan perhitungan yang dilakukan dengan menggunakan SPSS, diperoleh data sebagai berikut:

Tabel 1. Hasil Analisis Regresi Linier Berganda Coefficients ${ }^{\mathrm{a}}$

\begin{tabular}{|c|c|c|c|c|c|c|}
\hline & \multirow{2}{*}{ Model } & \multicolumn{2}{|c|}{ Unstandardized Coefficients } & $\begin{array}{l}\text { Standardized } \\
\text { Coefficients }\end{array}$ & \multirow{2}{*}{$\mathrm{T}$} & \multirow{2}{*}{ Sig. } \\
\hline & & B & Std. Error & Beta & & \\
\hline \multirow[t]{7}{*}{1} & (Constant) & 4.544 & 3.244 & & 6.950 & .000 \\
\hline & Metode & .509 & .250 & .279 & 2.033 & .054 \\
\hline & Tenaga Pengajar & .813 & .385 & .302 & 2.110 & .046 \\
\hline & Materi & .484 & .224 & .305 & 2.159 & .042 \\
\hline & Waktu & .966 & .380 & .403 & 2.541 & .018 \\
\hline & Lokasi & .532 & .262 & .310 & 2.027 & .054 \\
\hline & Fasilitas & .481 & .204 & .342 & 2.353 & .028 \\
\hline
\end{tabular}

a. Dependent Variable: Pengembangan Karir

Dari tabel di atas dihasilkan persamaan regresi sebagai berikut :

$\mathrm{Y}=\mathrm{a}+\mathrm{b}_{1} \mathrm{X}+\mathrm{b}_{2} \mathrm{X}_{2}+\mathrm{b}_{3} \mathrm{X}_{3}+\mathrm{b}_{4} \mathrm{X}_{4}+\mathrm{b}_{5} \mathrm{X}_{5}+\mathrm{b}_{6} \mathrm{X}_{6}+\mathrm{e}$

$\mathrm{Y}=4,544+0,509 \mathrm{X}_{1}+0,813 \mathrm{X}_{2}+0,484 \mathrm{X}_{3}+0,966 \mathrm{X}_{4}+0,532 \mathrm{X}+0,481 \mathrm{X}_{6}+\mathrm{e}$

Dari persamaan regresi tersebut dapat diketahui bahwa koefesien regresi komponen program pendidikan dan pelatihan $(\mathrm{X})$ yang terdiri dari metode, tenaga pengajar, materi, waktu, lokasi dan fasilitas semuanya memiliki tanda positif. Hal ini menunjukkan adanya indikasi hubungan yang searah antara variabel bebas yaitu komponen program pendidikan dan pelatihan $(\mathrm{X})$ yang terdiri dari metode, tenaga pengajar, materi, waktu, lokasi dan fasilitas dengan variabel terikat yaitu pengembangan karir (Y) pada Satuan Kerja Non Vertikal Tertentu (SNVT) Pembangunan Jalan dan Jembatan Provinsi NTB. 


\subsubsection{Analisis Determinasi Berganda}

Analisis determinasi berganda digunakan untuk menghitung seberapa besar variabel terikat yaitu pengembangan karir $(\mathrm{Y})$ dipengaruhi oleh variabel bebas yaitu program pendidikan dan pelatihan (X). Berikut hasil uji analisis determinasi berganda menggunakan SPSS

\section{Tabel 2. Hasil Analisis Determinasi Berganda}

Model Summaryb

\begin{tabular}{|c|r|r|r|c|}
\hline Model & \multicolumn{1}{|c|}{$\mathrm{R}$} & R Square & \multicolumn{1}{c|}{$\begin{array}{c}\text { Adjusted R } \\
\text { Square }\end{array}$} & $\begin{array}{c}\text { Std. Error of the } \\
\text { Estimate }\end{array}$ \\
\hline 1 & $.770^{\mathrm{a}}$ & .593 & .487 & 1.056 \\
\hline
\end{tabular}

a. Predictors: (Constant), Fasilitas, Metode, Tenaga Pengajar, Materi, Lokasi, Waktu

b. Dependent Variable: Pengembangan Karir

Dari tabel di atas diketahui koefesien determinasi berganda $\left(\mathrm{R}^{2}\right)$ sebesar 0,593 yang artinya besar pengaruh yang ditimbulkan oleh variabel program pendidikan dan pelatihan terhadap variabel pengembangan karir sebesar 59,3\%. Sedangkan yang disebabkan oleh faktor lainnya yang di luar penelitian ini adalah $1-0,593=0,407$ atau $40,7 \%$.

\subsubsection{Uji F}

Uji $\mathrm{F}$ digunakan untuk mengetahui ada atau tidaknya pengaruh variabel bebas yaitu program pendidikan dan pelatihan $(\mathrm{X})$ terhadap variabel terikat yaitu pengembangan karir $(\mathrm{Y})$ pada tingkat keyakinan (df) tertentu. Berdasarkan hasil pengujian dengan menggunakan alat analisis SPSS dapat diketahui hasil uji F pada tabel berikut :

Tabel 3. Hasil Uji F

\begin{tabular}{|c|c|c|c|c|c|c|}
\hline \multicolumn{7}{|c|}{ ANOVA $^{b}$} \\
\hline & Model & Sum of Squares & Df & Mean Square & $\mathrm{F}$ & Sig. \\
\hline 1 & Regression & 37.327 & 6 & 6.221 & 5.581 & $.001^{\mathrm{a}}$ \\
\hline & Residual & 25.640 & 23 & 1.115 & & \\
\hline & Total & 62.967 & 29 & & & \\
\hline
\end{tabular}

a. Predictors: (Constant), Fasilitas, Metode, Tenaga Pengajar, Materi, Lokasi, Waktu

b. Dependent Variable: Pengembangan Karir

Dari tabel di atas diperoleh $\mathrm{F}_{\text {hitung }}=5,581$ dan $\mathrm{F}_{\text {tabel }}=3,34$. Dengan demikian dapat disimpulkan bahwa Ho ditolak dan Ha diterima, yang artinya terdapat pengaruh yang signifikan dari variabel bebas yaitu program pendidikan dan pelatihan (X) terhadap variabel terikat yaitu pengembangan karir (Y) pada Satuan Kerja Non Vertikal Tertentu (SNVT) Pembangunan Jalan dan Jembatan Provinsi NTB.

\subsubsection{Uji t}

Uji $t$ digunakan untuk mengetahui ada atau tidaknya pengaruh variabel program pendidikan dan pelatihan $(\mathrm{X})$ yang terdiri dari metode, tenaga pengajar, materi, waktu, lokasi dan fasilitas secara parsial terhadap variabel pengembangan karir (Y). Hasil pengujian alat analisis SPSS dapat diketahui hasil uji t pada tabel berikut : 
Tabel 4. Hasil Uji t

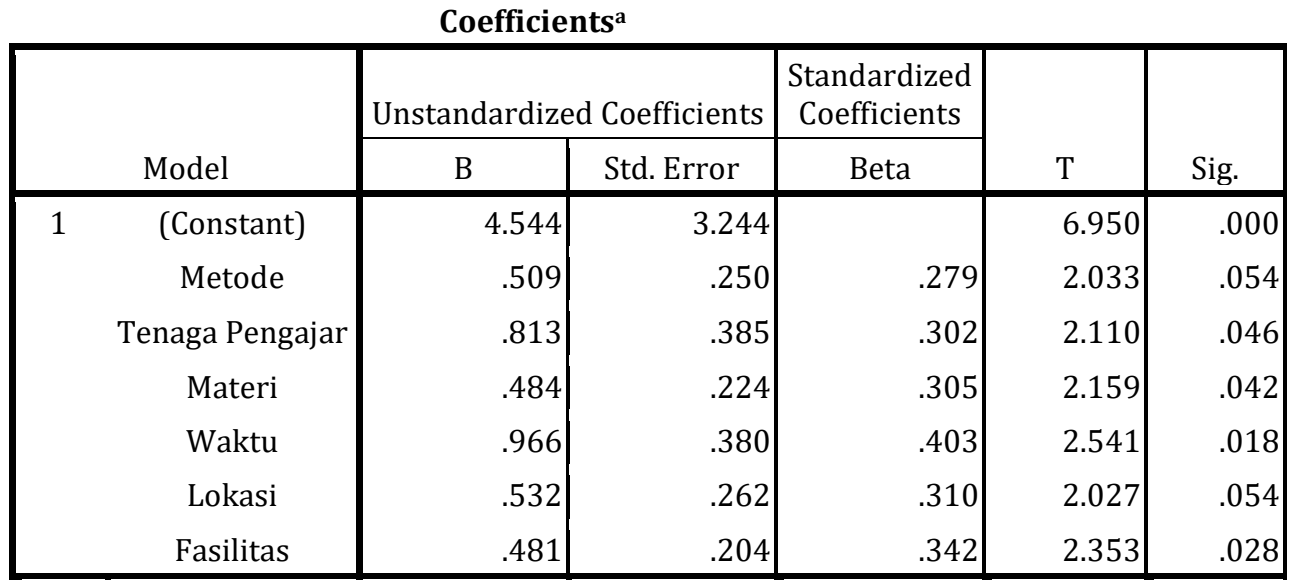

a. Dependent Variable: Pengembangan Karir

Dari tabel di atas dapat diuraikan sebagai berikut :

1. Menentukan Ho dan Ha

$\mathrm{Ho}=\mathrm{bt}=0$, artinya tidak terdapat pengaruh yang signifikan antara metode, tenaga pengajar, materi, waktu, lokasi dan fasilitas terhadap pengembangan karir.

$\mathrm{Ha}=\mathrm{bt} \neq 0$, artinya terdapat pengaruh yang signifikan antara metode, tenaga pengajar, materi, waktu, lokasi dan fasilitas terhadap pengembangan karir.

2. Menentukan tingkat keberartian/derajat keyakinan $(\alpha)$ sebesar $5 \%$ dan derajat kebebasan (df) $=\mathrm{n}-\mathrm{k}=30-2=28$. Karena pengujian bersifat dua arah ( $t$ wo tailed test), maka alpha $(\alpha)$ sebesar $0,05 / 2$ sama dengan 0,025 , dengan demikian letak $t$ tabel adalah pada titik $(\alpha / 2 ; \mathrm{df})$ yaitu $(0,025 ; 28)$ sama dengan 2,0484 .

3. Dari hasil analisa data uji t dengan bantuan program SPSS diperoleh nilai t hitung masing-masing variabel bebas yaitu komponen program pendidikan dan pelatihan yaitu : metode $(2,033)$, tenaga pengajar $(2,110)$, materi $(2,159)$, waktu $(2,541)$, lokasi $(2,027)$ dan fasilitas $(2,353)$, ini berarti Ho ditolak dan Ha diterima.

Dari keenam variabel bebas yang dimasukkan ke dalam model regresi dengan bantuan alat analisa SPSS diketahui variabel metode dan lokasi tidak signifikan, karena kedua variabel tersebut memiliki nilai signifikansi di atas 0,05, sedangkan keempat variabel lainnya diketahui signifikan, karena nilai signifikansi dari keempat variabel tersebut di bawah 0,05.

Dengan menggunakan Uji t ( $\alpha=5 \%$ ) menunjukkan bahwa thitung untuk variabel tenaga pengajar $\left(\mathrm{X}_{2}\right)$ sebesar 2,110, variabel materi $\left(\mathrm{X}_{3}\right)$ sebesar 2,159, variabel waktu $\left(\mathrm{X}_{4}\right)$ sebesar 2,541, serta variabel fasilitas $\left(\mathrm{X}_{6}\right)$ sebesar 2,353 lebih besar dari t tabel 2,0484 sehingga Ho ditolak, artinya secara parsial variabel tenaga pengajar, materi, waktu, dan fasilitas memiliki pengaruh yang signifikan terhadap pengembangan karir karyawan pada Satuan Kerja Non Vertikal Tertentu (SNVT) Pembangunan Jalan dan Jembatan Provinsi NTB, sedangkan kedua variabel lainnya yaitu variabel metode $\left(\mathrm{X}_{1}\right)$ sebesar 2,033 dan variabel lokasi $\left(\mathrm{X}_{5}\right)$ sebesar 2,027 lebih kecil dari t tabel 2,0484 sehingga Ho diterima, artinya secara parsial variabel metode dan lokasi tidak memiliki pengaruh yang signifikan terhadap pengembangan karir karyawan pada Satuan Kerja Non Vertikal Tertentu (SNVT) Pembangunan Jalan dan Jembatan Provinsi NTB.

\subsection{Pembahasan}

Pendidikan dan pelatihan merupakan salah satu upaya yang bisa dilakukan oleh setiap organisasi dalam proses pengembangan sumber daya manusia. Sebagai salah satu perusahaan yang melihat manfaat dari pengembangan sumber daya manusia, Satuan Kerja Non Vertikal Tertentu (SNVT) Pembangunan Jalan dan Jembatan Provinsi NTB secara rutin mengadakan program pendidikan dan pelatihan bagi karyawannya. Hal ini bertujuan agar program pendidikan dan pelatihan yang diberikan oleh instansi dapat tercapai. Seperti yang dikemukakan Handoko (2011) bahwa tujuan utama dari program pendidikan dan pelatihan 
adalah untuk menutup "gap" antara kecakapan atau kemampuan karyawan dengan permintaan jabatan, serta untuk meningkatkan efisiensi dan efektivitas kerja karyawan dalam mencapai sasaran-sasaran kerja yang telah ditetapkan.

Selanjutnya berdasarkan hasil analisa regresi linear berganda dari uji F diketahui bahwa program pendidikan yang terdiri dari metode, tenaga pengajar, materi, waktu, lokasi dan fasilitas mempunyai pengaruh yang signifikan terhadap pengembangan karir, hal tersebut dibuktikan dengan melihat nilai perbandingan antara $\mathrm{F}$ hitung dengan $\mathrm{F}$ tabel, dimana nilai $\mathrm{F}$ hitung lebih besar dibandingkan dengan $F$ tabel yaitu sebesar 5,581 > 3,34 dengan derajat signifikan 0,001 jauh lebih kecil dari 5\% sehingga variabel pendidikan dan pelatihan memiliki pengaruh yang cukup kuat terhadap pengembangan karir karyawan Satuan Kerja Non Vertikal Tertentu (SNVT) Pembangunan Jalan dan Jembatan Provinsi NTB, hal tersebut ditunjukan berdasarkan nilai koefisien diterminasi berganda $\left(\mathrm{R}^{2}\right)$ yang mencapai angka sebesar 59,3 \%.

Berdasarkan hasil uji t yang dilakukan pada variabel pendidikan dan pelatihan yang terdiri dari metode, tenaga pengajar, materi, waktu, lokasi dan fasilitas, maka dapat diketahui hanya empat variabel yang memiliki pengaruh signifikan terhadap pengembangan karir karyawan Satuan Kerja Non Vertikal Tertentu (SNVT) Pembangunan Jalan dan Jembatan Provinsi NTB yaitu tenaga pengajar $(2,110)$, materi $(2,159)$, waktu $(2,541)$, dan fasilitas $(2,353)$, karena memiliki nilai t hitung lebih besar dibandingkan dengan t tabel $(2,0484)$ dan hal tersebut dibuktikan dengan melihat besarnya derajat signifikansi yang berada di bawah 5\%. Sedangkan untuk variabel metode $(2,033)$ dan lokasi $(2,027)$ tidak memiliki pengaruh yang signifikan terhadap pengembangan karir, karena memiliki nilai t hitung lebih kecil jika dibandingkan dengan nilai t tabel $(2,0484)$ dan memiliki derajat signifikansi yang dicapai dari hasil analisa data adalah melebihi 5\%.

\section{Kesimpulan}

Berdasarkan uraian hasil penelitian yang telah dilakukan mengenai pengaruh pendidikan dan pelatihan terhadap pengembangan karir karyawan pada Satuan Kerja Non Vertikal Tertentu (SNVT) Pembangunan Jalan dan Jembatan Provinsi NTB, dapat disimpulkan sebagai berikut :

1) Terdapat pengaruh yang signifikan secara simultan dari komponen program pendidikan dan pelatihan yang terdiri dari metode, tenaga pengajar, materi, waktu, lokasi, dan fasilitas terhadap pengembangan karir karyawan pada Satuan Kerja Non Vertikal Tertentu (SNVT) Pembangunan Jalan dan Jembatan Provinsi NTB. Hal ini sesuai dengan hasil uji F dimana F hitung lebih besar dibandingkan dengan $\mathrm{F}$ tabel yaitu 5,581 > 3,34.

2) Terdapat pengaruh yang signifikan secara parsial dari komponen program pendidikan dan pelatihan yang terdiri dari metode, tenaga pengajar, materi, waktu, lokasi, dan fasilitas terhadap pengembangan karir karyawan pada Satuan Kerja Non Vertikal Tertentu (SNVT) Pembangunan Jalan dan Jembatan Provinsi NTB. Hal ini sesuai dengan hasil uji t di mana t hitung masing-masing komponen program pendidikan dan pelatihan yang terdiri dari metode $(2,033)$, tenaga pengajar $(2,110)$, materi $(2,159)$, waktu $(2,541)$, lokasi(2,027), dan fasilitas $(2,353)$ lebih besar dari nilai t tabeln yaitu sebesar 2,0484 .

\section{Daftar Pustaka}

Azizah, Z. Z. N. (2019). Pendidikan Dan Pelatihan Sebagai Upaya Peningkatan Kinerja Pegawai Perpustakaan. Jurnal Dinamika Manajemen Pendidikan, 3(2), 96. https://doi.org/10.26740/jdmp.v3n2.p96-100

Balbed, A., \& Sintaasih, D. K. (2019). Pengaruh Pengembangan Karir Terhadap Kinerja Karyawan Melalui Pemediasi Motivasi Kerja Karyawan. E-Jurnal Manajemen Universitas Udayana, 8(7), 4676. https://doi.org/10.24843/ejmunud.2019.v08.i07.p24

Dessler, G. (2015). Human Resources Management (Manajemen Sumber Daya Manusia) Edisi 14. Jakarta: Indeks. 
Eliana, Nurhayati, \& Fathiah. (2020). Pengaruh Pendidikan Dan Pelatihan (Diklat) Terhadap Kinerja Pegawai Pada Badan Pengembangan Sumber Daya Manusia (BPSDM) Aceh. ZONAsi: Jurnal Sistem Informasi, 2(2), 84-95.

Hadjri, I. M., \& Perizade, B. (2019). Pengaruh Pendidikan dan Pelatihan terhadap Kinerja Pegawai pada Bank Sumsel Babel Syariah. Jurnal Manajemen Dan Bisnis Sriwijaya, 16(3), 142-152. https://doi.org/10.29259/jmbs.v16i3.7377

Handayani, D. (2019). Pengaruh Pendidikan dan Pelatihan, Motivasi, Serta Lingkungan Kerja Terhadap Kinerja Guru SMK Negeri Banyuasin. Jurnal Ilmu Manajemen, 6(2), 140. https://doi.org/10.32502/jimn.v6i2.1583

Handoko, T. H. (2011a). Manajemen Personalia dan Sumber Daya Manusia. Pengantar Manajemen.

Handoko, T. H. (2011b). Manajemen Personalia dan Sumber Daya Manusia. In Pengantar Manajemen.

Mathis, R. L., \& Jackson, J. H. (2012). Manajemen Sumber Daya Manusia. In Manajemen Sumber Daya Manusia.

Mufidah, S., Mursito, B., \& Kustiyah, E. (2020). Pelatihan Kerja, Motivasi Dan Pengembangan Karir Pengaruhnya Terhadap Kinerja Karyawan Pada Pt. Rifan Financindo Berjangka Solo. Jurnal Ilmiah Edunomika, 4(01), 145-154. https://doi.org/10.29040/jie.v4i01.830

Nurhasan, R., \& Saoqi, M. (2016). Pengaruh Pengalaman Kerja, Pendidikan dan Pelatihan (Diklat) Terhadap Pengembangan Karir pada PT. BPRS PNM Mentari Garut. (2016), 1-8.

Prasetyo, A. I., \& Relawan, I. N. (2017). Analisis Pengaruh Pendidikan dan Pelatihan terhadap Kinerja melalui Kompetensi (Studi pada unit SDM PT Kereta Api Indonesia (Persero) Bandung). Ecodemica, 1(1), 107-117. Retrieved from https://ejournal.bsi.ac.id/ejurnal/index.php/ecodemica/article/view/1553

Sartika, D. (2018). Pengaruh Pendidikan dan Pelatihan, Kompensasi dan Motivasi terhadap Kinerja Karyawan pada Rumah Sakit Bhineka Bakti Husada Tangerang Selatan. Kreatif, 6(4).

Sastrohadiwiryo, S. (2003). Manajemen Tenaga Kerja Indonesia. Jakarta: Bumi Aksara.

Sugiyono. (2012). Metode Penelitian Kuantitatif, Kualitatif dan R \& D.Bandung:Alfabeta. Metode Penelitian Kuantitatif, Kualitatif Dan $R \quad \& \quad$ D.Bandung:Alfabeta. https://doi.org/10.1017/CB09781107415324.004

Swastha, B., \& Handoko, T. H. (2012). Manajemen Pemasaran: Analisa Perilaku Konsumen. Yogyakarta: BPFE UGM.

Umiyati, H., Anwar, K., \& Ustadztama, M. G. (2020). Performance of Auditing Staff At the Directorate. Jurnal Sekretari \& Administrasi (Serasi), 18(2), 57-68.

Wijono, S. (2015). Psikologi Industri Dan Organisasi. Prenada.

Wirawan. (2015). Manajemen Sumber Daya Manusia Indonesia. In Depok. 